\title{
EFEKTIVITAS PENERAPAN PENGENDALIAN DAN PENGAWASAN MIRAS DI MAKASSAR
}

\author{
Hj. Rahmatiah
}

Fakultas Syariah dan Hukum UIN Alauddin Makassar

\begin{abstract}
Liquor that often cause various social problems and security bacam cause Makassar mayor issued rules on control and supervision area Miras. The purpose of this study was to determine the response of society on the application of controls and pengwasan alcohol, factors that affect the problems of alcohol, and will see how far the effectiveness of the regulation of alcohol. The method used is descriptive kuanitatif by taking 100 informants as a sample to represent the population of city residents Makassar.Dari results showed considerable public support the government's efforts in the implementation of the rules of alcohol, but has not been effective because of the lack of regulation enforcement supervisor portion primarily related to Miras.
\end{abstract}

\section{Keywords:}

Effectiveness, Regulatory Area and Miras

\begin{abstract}
Abstrak
Minuman keras yang acapkali menimbulkan berbagai bacam problem sosial dan keamanan menyebabkan wali kota Makassar mengeluarkan aturan daerah tentang Pengendalian dan Pengawasan Miras. Tujuan dari penelitian ini adalah untuk mengetahui tanggapan masyarakat tentang penerapan pengendalian dan pengwasan miras, Faktor-faktor yang berpengaruh terhadap problematika miras, dan akan melihat sejauhmana efektivitas Perda tentang miras. Metode yang digunakan adalah kuanitatif deskriptif dengan mengambil 100 informan sebagai sampel untuk mewakili populasi warga kota Makassar.Dari hasil penelitian menunjukkan masyarakat cukup mendukung upaya pemerintah dalam aturan penerapan miras, akan tetapi belum efektif karena kurangnya porsi pengawas Penegak Perda utamanya yang berkaitan dengan Miras.
\end{abstract}

Kata Kunci:

Efektivitas, Peraturan daerah dan Miras 


\section{A. LATAR BELAKANG MASALAH}

$\mathrm{P}$ enyalahgunaan minuman keras mengakibatkan munculnya berbagai macam problema sosial dalam masyarakat antara lain: kenakalan remaja, perkelahian, munculnya geng-geng motor, perbuatan asusila, dan maraknya premanisme, semuanya merupakan permasalahan yang cukup menyita perhatian pemerintah, LSM, ormas, bahkan masyarakat pun turut membicarakan tentang bahaya miras di setiap wilayah Indonesia, tak terkecuali Makassar, terbukti dengan dikeluarkannya peraturan daerah nomor 4 tahun 2014 tentang pengendalian dan pengawasan minuman keras. Pemerintah daerah mencurahkan pemikirannya untuk mengatasi berbagai macam kejahatan akibat pengaruh minuman keras, Di tempat lain, Gubernur Maluku, Said Assegaff menilai pentingnya peraturan untuk membatasi peredaran minuman keras, sebab menurut beliau 90\% tindak kejahatan karena pengaruh minuman keras; setiap kali ada keributan, tawuran antar kampung karena mabuk, akhirnya ribut. ${ }^{1}$

Minuman keras merupakan minuman yang membahayakan, membuat seseorang berperasaan dan berfikir tidak sehat. Miras mampu membawa penggemarnya menjadi ketagihan dan bahkan ke stadium ketergantungan, namun sebagian anggota masyarakat menyenanginya. Pengaruh minuman keras menimbulkan banyak masalah dalam masyarakat yaitu terjadinya berbagai tindak pidana kekerasan, antara lain: penganiayaan, pencurian, zina/cabul/asusila, perkosaan, pengrusakan, pembunuhan, membuat keributan di malam hari, menghentikan kendaraan di jalan kemudian meminta uang untuk beli minuman keras, dan sebagainya.

Seseorang yang mengkomsumsi miras berarti orang itu tidak memelihara akal sehatnya sedangkan dalam tujuan syariat adalah memelihara akal. Tanpa akal sehat manusia itu akan merusak dirinya dan orang lain. Rasulullah saw, bersabda:

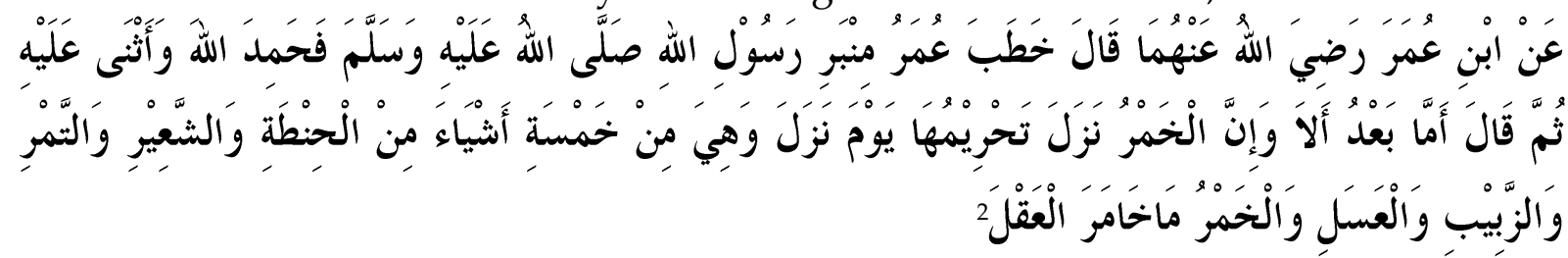

Artinya:

"Diriwayatkan dari Ibnu Umar ra. katanya: Umar telah berkhutbah di atas mimbar Rasulullah saw. Beliau mengucap syukur kepada Allah dan memuji-Nya, kemudian dia berkhutbah: Sesungguhnya arak telah diharamkan oleh Allah berdasarkan ayat Alquran. Arak yang dimaksud, terdiri dari lima macam jenis, yaitu gandum, barli, tamar, zabib dan madu. Arak ialah benda yang boleh menyebabkan hilang akal yaitu mabuk".

\footnotetext{
${ }^{1} \mathrm{http}: / / w w w . g a t r a . c o m / n u s a n t a r a-1 /$ maluku-papua/134876-jadi-biang-tindak-kriminal,-gubernur-malukuakan-batasi-miras.html, diakses pada hari sabtu, tanggal 20 Februari.

${ }^{2}$ Hadis ini dikutip dari CD Holy Quran \& Alhadis: Kumpulan Hadis Riwayat Bukhary \& Muslim, 2002, hadis No. 1743.
} 
Dampak yang luar biasa yang ditimbulkan oleh miras, menyebabkan sejumlah daerah mengeluarkan peraturan pengendalian dan pengawasan miras, antara lain provinsi Sumatera Selatan dengan perdanya nomor 10 tahun 2011 tentang pengawasan, penertiban dan pengendalian minuman beralkohol, dan Makassar pun tak kalah prihatinnya akan bahaya miras dengan daerah lain, sehingga mengeluarkan perda nomor 4 tahun 2014 tentang pengawasan dan pengendalian pengadaan, peredaran dan penjualan minuman beralkohol. Dalam aturan ini diberi batasan yang boleh menjual miras, yaitu hotel,pub, tempat karaoke, diskotik, dan bar. Di tempat lain, Pemerintah Pusat mengeluarkan peraturan lewat Menteri Perdagangan, yaitu Permendag RI nomor 06/M-DAG/PER/1/2015.

Regulasi minuman keras banyak menimbulkan pro dan konta. Di satu pihak menilai bahwa adanya ketentuan yng mengatur minuman keras dalam masyarakat berkenaan dengan izin penjualan minuman keras, maka dengan sendirinya turut melegalkan minuman keras untuk dikomsumsi masyarakat. Sedangkan di pihak lain keberadaan perda anti miras bukan berarti untuk menghalalkan hukumnya untuk mengomsumsi miras, melainkan untuk melakukan pengawasan yang efektif terhadap pengedaran minuman keras di masyarakat sehingga setiap orang atau badan hukum tidak sekehendak hatinya menjual minuman keras tanpa didasarkan atas izin penjualan.

Regulasi tentang minuman keras diterapkan untuk melindungi masyarakat dari gangguan ketertiban dan ketenteraman masyarakat. Permendag RI dan PERDA adalah kebijakan dan wewenang pemerintah untuk melarang peredaran dan penjuaalan minuman keras secara bebas. Berdasarkan hal tersebut, maka usaha penjualan dan proses perizinan minuman keras perlu diatur sehingga pelaku usaha tidak sembarangan mengedarkan dan menjual minuman keras di masyarakat. Hadirnya Perda nomor 4 tahun 2014 tentang pengawasan, dan pengendalian miras di Makassar menunjukkan semangat pemerintah daerah untuk menciptakan masyarakat yang sehat dan bermartabat, disamping itu peran masyarakat setempat untuk menghentikan masalah miras sangat dibutuhkan. Peran tokoh masyarakat, tokoh agama, dan pemerintah secara tegas menolak penyebaran miras perlu dilakukan secara efektif dan berkesinambungan dan terus menyuarakan gerakan anti-miras kepada seluruh masyarakat dan kalangan generasi muda.

Berdasar atas alasan di atas, maka penulis terpanggil untuk melakukan riset dan study lapangan untuk meninjau langsung pengetahuan masyarakat tentang penerapan regulasi aturan atas miras, demikian pula dengan regulasi Permendag RI tahun 2015, dan akan diselaraskan dengan Perda nomor 4 tahun 2014 tentang pengendalian dan pengawasan miras di Makassar, apakah sudah berjalan efektif atau malah sebaliknya. Dengan tujuan untuk mengetahui tanggapan masyarakat tentang penerapan pengendalian dan pengwasan miras, Faktor-faktor yang berpengaruh terhadap problematika miras, dan akan melihat sejauhmana efektivitas Perda tentang miras. 


\section{B. KERANGKA TEORI}

\section{Teori Efektivitas}

Menurut kamus besar Bahasa Indonesia, kata efektif mempunyai arti efek, pengaruh, akibat atau dapat membawa hasil. Jadi, efektivitas adalah keaktifan, daya guna, adanya kesesuaian dalam suatu kegiatan orang yang melaksanakan tugas dan sasaran yang dituju. ${ }^{3}$

Efektivitas pada dasarnya menunjukkan pada taraf tercapainya hasil, sering atau senantiasa dikaitakan dengan pengertian efisien, meskipun sebenarnya ada perbedaan diantara keduanya. Efektivitas menekankan pada hasil yang dicapai, sedangkan efisiensi lebih melihat pada bagaimana cara mencapai hasil yang dicapai itu dengan membandingkan antara input dan out-putnya.

Pengertian tersebut di atas, menunjukkan bahwa efektivitas adalah suatu keadaan yang menunjukkan sejauhmana rencana dapat tercapai. Semakin banyak rencana yang dapat dicapai, semakin efektif pula kegiatan tersebut. Atau dengan kata lain jika dihubungkan dengan hukum, maka dapat disimpulkan bahwa penerapan hukum itu berhasil atau tidak tergantung pada seberapa besar usaha dan cara yang dipakai untuk menerapkan regulasi/ hukum tertentu dalam masyarakat. Penerapan hukum dikatakan efektif bila tercapai usaha atau cara menerapan hukum itu.

\section{Teori Kebijakan publik}

Kebijakan secara harfiah terjemah dari policy ${ }^{4}$, dalam bahasa Yunani berarti "Negara kota" sedangkan dalam bahasa Inggris diartikan sebagai urusan pemerintahan. ${ }^{5}$

Kebijakan publik dalam wacana kekuasaan dimaknai oleh Thomas R Dye adalah apapun yang dipilih pemerintah untuk dilakukan atau tidak dilakukan (whatever government choose to do or not to do). ${ }^{6}$ Sementara itu David Easton (dalam Miftah Thoha,1984) memberikan pemahaman kebijakan publik sebagai; "Alokasi nilai yang oritatif untuk seluruh masyarakat akan tetapi hanya pemerintahlah dapat berbuat secara otoritatif untuk seluruh masyarakat dan semuanya yang dipilih oleh pemerintah untuk dikerjakan atau untuk tidak dikerjakan adalah hasil-hasil dan alokasi nilai-nilai tersebut".

Pengertian lain adalah Rangkaian konsep atau asas yang menjadi pedoman dan dasar rencana dalam pelaksanaan suatu pekerjaan, kepemimpinan organisasi atau kelompok. Kebijakan dapat merujuk pada proses pembuatan keputusan-keputusan penting organisasi, termasuk identifikasi berbagai alternative seperti prioritas program atau pengeluaran, dan pemilihan berdasarkan dampaknya. Kebijakan dapat pula diartikan sebagai mekanisme politis, manajemen, finansial, atau

\footnotetext{
${ }^{3}$ www.literaturbook.blogspot.co.id

${ }^{4}$ http:www.edonbiu.com/2009/04ilmukebijakan-dan-pengertiankebijakan.htmi (diakses jumat 22 januari 2010)

${ }^{5}$ WilliamDunn, http.www.edondiu.com/2009/04ilmukebijakan-danpengertiankebijakan.htmi, (diakses jumat, tanggal 22 Januari 2010)

${ }^{6}$ http://id.wikipedia.org/wiki/kajiankebijakan (diakses jumat, 22 januari 2010)
} 
administrative,untuk mencapai tujuan eksplisit. ${ }^{7}$

Kebijakan umumnya dikaitkan dengan keputusan pemerintah, karena pemerintahlah yang berwenang atau mempunyai kekuasaan untuk mengarahkan masyarakat. Atau dengan kata lain keputusan pemerintah yang relative bersifat umum dan ditujukan kepada masyarakat umum.

Pengertian tersebut di atas sejalan dengan penggunaan kata "kebijaksaan oleh Lembaga Administrasi Negara Republik Indonesia, dimana Kebijaksaan diartikan sebagai:

Ketentuan-ketentuan yang harus dijadikan pedoman, pegangan atau petunjuk bagi setiap usaha dan kegiatan aparatur pemerintah, sehingga tercapai kelancaran dan keterpaduan dalam upaya mencapai tujuan. Kebijaksanaan dapat dibedakan sebagai kebijakan internal dan ekstemal, tertulis dan tidak tertulis...."

Dengan demikian dapat dipahami bahwa perhatian kebijakan publik tidak hanya menyorot apa saja yang dilakukan oleh pemerintah, termasuk juga apa yang tidak dilakukan oleh pemerintah.

Kebijakan publik adalah hasil dan pelaksanaan fungsi politik, merupakan wahana dari pemerintahan untuk secara rasional menguasai dan mengendalikan aktivitas sosial.Kebijakan publik merupakan arahan yang sifatnya otoritatif dari pemerintah, yang dioperasionalkan melalui peraturan perundang-undangan, strategi, perencanaan, aneka intervensi pemerintah terhadap kehidupan sosial ekonomi masyarakat dan lain-lain tindakan pemerintah yang sifatnya fundamental.Tujuan yang ingin dicapai pemerintah, nilai-nilai yang ingin diwujudkan, serta aneka permasalahan kemasyarakatan yang muncul, penyelesaiannya dilakukan melalui kebijakan publik.

Berkaitan dengan upaya pengembangan organisasi publik, biasanya keefektifan organisasi selalu menjadi tujuan yang utama. Keefektifan organisasi ini sangat tergantung pada bagaimana upaya organisasi yang relative sangat adaptif terhadap perubahan lingkungan.Solichin Abdul Wahab (1997) dalam kaitannya dengan mendesain organisasi menguraikan empat pendekatan implementasi kebijakan yaitu pendekatan struktural (structural approaches), pendekatan prosedural dan manajerial (procedural and managerial approaches), pendekatan keprilakukan (behavioural approaches) dan pendekatan politik (political approaches).

Berkaitan dengan penataan Organisasi Perangkat Daerah Provinsi Sulawesi Selatan, keempat pendekatan implementasi kebijakan tersebut bisa saja mewarnai pembahasan.Namun dalam mendesain kelembagaan perangkat daerah strategi manajemen dari elit lokal sangatlah berpengaruh. Sebab dengan dikeluarkannya Peraturan Pemerintah RI Nomor 6 Tahun 2003 maka ketentuan besaran organisasi ditetapkan.Memformulasikan kelembagaan perangkat daerah merupakan bentuk

\footnotetext{
${ }^{7}$ http://id.wikipedia.org/wiki/kajiankebijakan (diakses jumat, 22 januari 2010)

${ }_{8}^{8}$ Lembaga Administrasi Negara Republik Indonesia, jilid II/Edisi ketiga (Jakarta: Gunung Agung, 1997), h. 2
} 
implementasi kebijakan Pemerintah Pusat di daerah. Dengan demikian memformulasikan besaran jumlah perangkat daerah harus melihat peraturan pemerintah tolok ukur yang harus dipenuhi sebagai standar norma. Dengan mengingat keberlakuan peraturan pemerintah sebagai standar normatif maka hanya elit manajer yang mempunyai kewenangan dalam memformulasikan kelembagaan perangkat daerah.

\section{METODOLOGI PENELITIAN}

\section{Jenis dan Lokasi Penelitian}

Dalam penelitian ini akan disajikan jenis penelitian normatif kuantitatif yang bersifat eksploratif dan deskriptif. Eksploratif dan deskriptif adalah penyajian data yang dikembangkan dari teori-teori kebijakan publik dikembangkan dan diuraikan secara tuntas dan jelas;

Sedangkan Lokasi Penelitian akan dilakukan di kota Makassar, Namun karena terbatasnya waktu dan dana, maka peneliti hanya fokus pada tiga kecamatan saja.

2. Pendekatan Penelitian; pendekatan syar'i, yuridis, dan, filosifis, psikologis dan sosiologis

3. Populasi dan Sampel

a. Populasi

Populasi penelitian ini mencakup seluruh tempat-tempat hiburan malam yang terdapat di Makassar, yaitu leboh dari 2000 tempat hiburan malam yang terdiri dari: hotel pub, Bar, Diskotik, dan tempat-tempat karaoke. Begitu pula dengan ritel-ritel, dan swalayan yang ada di wilayah Makassar. Berdiri dan sangat dekat dengan pemukiman masyarakat, tumbuh dan berkembang semakin menjamur. Tempat- tempat inilah yang biasanya menjual minuman keras.

b. Sampel

Oleh karena jumlah tempat-tempat yang disebutkan dalam permendag dan perda sangat banyak dan tersebar diseluruh wilayah, daerah, bahkan perkampungan masyarakat, maka peneliti membatasi di 3 (tiga) kecamatan, dimana akan ditelusuri lebih jauh lagi daerah yang paling rawan dengan peredaran minuman keras ini. Teknik penarikan sampelnya dengan menggunakan rumus Slovin sebagai berikut:

$$
\mathrm{n}=\frac{N}{1+N e^{2}}
$$

Keterangan:

$\mathrm{n}=$ Jumlah Sampel

$\mathrm{N}=$ Besar Populasi

$\mathrm{e}=$ Tingkat Kepercayaan $(5 \%=0.05)$

Sedangkan sampel dibatasi hingga 100 orang di Makassar. 


\section{Metode Pengumpulan data}

Metode pengumpulan data adalah teknik atau cara-cara yang dapat digunakan oleh peneliti untuk mengumpulkan data dengan menggunakan kuesioner. Sedangkan pengumpulan data dilakukan dengan menggunakan teknik purposive sampling berdasarkan karakteristik tertentu. Di samping itu wawancara secara mendalam (indepth interviews).

\section{Instrumen Penelitian}

Untuk mengumpulkan data menggunakan intrumen yang telah peneliti buat, berdasarkan bahan bacaan yang akan digunakan untuk melakukan pengukuran yang bertujuan untuk menghasilkan data kuantitatif meski dalam bentuk frekwensi. Instrumen tersebut menggunakan skala Likert untuk mengukur pendapat, sikap ataupun respon masyarakat dalam hal pengendalian dan pengawasan distribusi minuman keras di masyarakat. Instrumen tersebut tertuang dalam daftar Wawancara terstruktur.

\section{Teknik Pengolahan dan Analisis Data}

Teknik analisis dalam penelitian ini menggunakan dua macam program statistik, yaitu (1) analisis deskriptif, yang menjelaskan mengenai karakteristik responden khususnya dalam hubungannya dengan variable-variabel penelitian. (2) analisis inferensial (inferencial statistic).

\section{PEMBAHASAN}

\section{Profil Kota Makassar}

Secara administrasi kota ini terdiri dari 14 kecamatan dan 143 kelurahan. Kota ini berada pada ketinggian antara 0-25 m dari permukaan laut. Penduduk Kota Makassar pada tahun 2000 adalah 1.130.384 jiwa yang terdiri dari laki-laki 557.050 jiwa dan perempuan 573.334 jiwa dengan pertumbuhan rata-rata 1,65\%. Masyarakat Kota Makassar terdiri dari beberapa etnis yang hidup berdampingan secara damai seperti Etnis Bugis, etnis Makassar, etnis Cina, etnis Toraja, etnis Mandar dll. Kota dengan populasi 1.112.688 jiwa ini, mayoritas penduduknya beragama Islam. Dalam sejarah perkembangan Islam, Makassar adalah kota kunci dalam penyebaran agama Islam ke Kalimantan, Philipina Selatan, NTB dan Maluku. Munculnya kasus SARA di AmbonMaluku dan Poso pada beberapa tahun terakhir ini, tidak terlepas dari peran strategis Makassar sebagai kota pintu di wilayah Timur Indonesia. Kekristenan di Makassar dalam beberapa tahun terakhir ini sering menjadi sasaran serbuan. ${ }^{9}$

Kota Makassar disamping sebagai daerah transit para wisatawan yang akan menuju ke Tana Toraja dan daerah-daerah lainnya, juga memiliki potensi obyek wisata seperti : Pulau Lae-lae, Pulau Kayangan, Pulau Samalona, Obyek wisata peninggalan sejarah lainnya seperti: Museum Lagaligo, Benteng Somba Opu, Makam Syech Yusuf, makam Pangeran Diponegoro, Makam Raja-raja Tallo, dan lain-lain.

\footnotetext{
${ }^{9}$ www. Makassar Dalam angka 2012
} 
Fasilitas penunjang tersedia jumlah hotel 95 buah dengan jumlah kamar 3.367 cottage wisata sebanyak 76 buah, selain itu juga terdapat obyek wisata Tanjung Bunga yang potensial.

Keberadaan minuma keras (miras) dengan kadar alkohol rendah merupakan penunjang pariwisata. Hal ini dibuktikan dengan tingginya konsumsi terhadap minuman jenis ini yang berdampak pada berkembangnya PT Delta Djakarta yang merupakan Badan Usaha Milik Daerah (BUMD) yang memproduksi bir merk Anker. Adapun PT Delta Djakarta ditargetkan memperoleh pendapatan sebesar Rp1,3 triliun. Dampak miras ini dirasakan oleh daerah wisata seperti Makassar, bahkan dapat disimpulkan bahwa dinamika perkembangan kota Makassar pun tidak terlepas dari Miras. ${ }^{10}$

\section{Miras Dalam Hukum Islam}

Kata miras dipahami sebagai nama minuman yang membuat peminumnya mabuk atau kehilangan kesadaran. Proses membuatan dan komsumsi minuman memabukkan ini dahulu orang membuatnya secara tradisional, yaitu dari perasan buah yang melalui prosess permentasi kemudian dikomsumsi dalam bentuk cair, namun pada zaman yang global dan modern ini dilakukan bermacam-macam cara, dari yang tradisional hingga menggunakan teknologi modern, dan miras yang dihasilkan pun bukan lagi dalam bentuk cair melainkan sudah dikemas dalam bentuk makanan, minuman, tablet, kapsul, atau serbuk.

Minuman atau makanan yang memabukkan ini Rasulullah saw, telah memberi isyarat bahwa hukumnya haram. Sabda Rasulullah SAW:

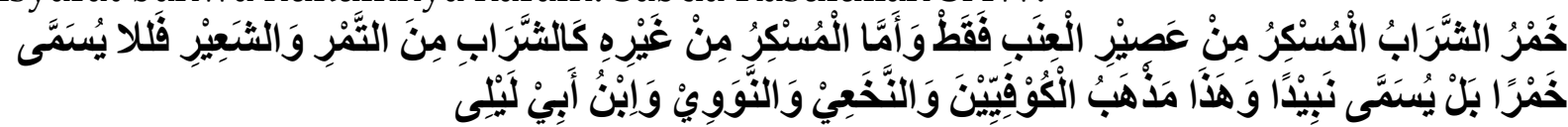

Artinya:

"Khamer adalah minuman yang memabukkan yang berasal dari perasan anggur saja. Adapun yang memabukkan dari selain anggur, seperti minuman yang terbuat dari perasan kurma dan gandum, maka tidak dinamakan khamer, akan tetapi dinamakan nabidz. Ini adalah madhabnya ulama Kufah, Al-Nakha'I, Al-Tsauri dan Ibnu Laila"

"Dari Ibnu Umar ra. bahwa Rasulullah saw. Bersabda: "Setiap yang memabukkan adalah khamr, dan setiap yang memabukkan adalah haram (Riwayat Muslim).

Para fuqaha ada yang mengartikan khamr sebagai cairan yang memabukkan yang diperoleh dari perasan buah-buahan, maupun biji-bijian, yang dikomsumsi dalam bentuk cair, namun sebagian fuqaha lain ada yang berpendapat bahwa khamr adalah semua jenis makanan dan minuman yang memabukkan baik yag diambilfari buah-buahan ataupun biji-bijian seperti kurma anggur, dan gandum, baik benbentuk cair maupun padat, baik dalam kemasan tradisional maupun dalam kemasan seperti di zaman modern ini, kesemuanya itu adalah termasuk khamr dan haram menurut

\footnotetext{
${ }^{10}$ http://poskotanews.com/2016/05/24/miras-beralkohol-rendah-penunjang-pariwisata-jakarta/
} 
fuqaha. ${ }^{11}$

Pendapat tersebut di atas sejajalan sejalan dengan apa yang termaktub dalam hukum Islam, yaitu minuman memabukkan tidak hanya terbatas pada benda cair saja, akan tetapi termasuk juga minuman atau makanan dalam bentuk benda padat, hal ini dikoneksikan dengan apa yang telah disabdakan Rasulullah bahwa: "semua yang memabukkan adalah Haram" (kullu musykirin haram).

Jadi miras adalah minuman yang memabukkan baik dibuat dari proses tradisional maupun secara modern, dan dikemas dalam bentuk cair maupun padat hukumnya haram dikomsumsi, baik dalam jumlah sedikit, apalagi dalam jumlah yang banyak.

\section{Faktor-Faktor Penyebab}

Manusia dilahirkan ke dunia dalam bentuk fitrah,namun ada pengaruhpengaruh yang datang kemudian sehingga seseorang itu bisa berubah menjadi orang yang berperangai buruk, termasuk kepribadian ganda, kepribadian dibawah pengaruh miras, dan sebagainya. Semua itu dapat dialami seseorang yang dinamai manusia karena faktor lingkungan dan dari dirinya sendiri, namun yang paling banyak berpengaruh adalah factor lingkungan sekitarnya. Faktor-faktor yang dimaksud adalah:

'a. Faktor Keluarga

Keluarga mempunyai peranan penting di dalam pendidikan dan dalam pembentkan karakter anak. Anak yang sejak lahir diasuh oleh orang tuanya penuh kasih, cinta dan perhatian tentu saja dapat mempunyai anak berkarakter dan berakhlaq baik. Sebaliknya anak yang dilahirkan oleh orang tua yang kurang peduli pada anaknya ditambah sulitnya perekonomian keluarga, dan semakin memperburuk atmosfir keluarga dengan adanya pertengkaran orang tuanya, menyebabkan sang anak lepas dari bimbingan arahan dari orang tuanya, atauboleh jadi sag anak hidup dalam serba kecukupan namun orang tuanya sibuk mencari nafkah, sibuk kegiatan sosial sehingga hamper tak tersisa waktu untuk berdialog dengan anaknya, ini pun berdampak buruk pada anak yang menyebabkan sang anak akan kehilangan jati dirinya dan akan mencari lingkungan yang lain yang lebih peduli pada keadaannya, pengaruh emosi, kejiwaan dan semacamnya menyebabkan sang anak merusak dirinya dengan lari pada minuman yang membuatnya dapat melupakan kekecewaannya sesaat, dapat beralusinasi sesaat. Itulah Minuman beralkohol atau miras.

b. Faktor Lingkungan Tempat Tinggal

Tempat tinggal yang terlalu padat penduduknya dan suasana hiburan yang menggoda, gaya hidup yang menglobal memaksakan dan menggoda anak-anak untuk melihat dan mengamati tempat-tempat hiburan, sehingga muncul dalam benaknya rasa penasaran ingin menikmati minuman yang diharamkan tetapi dapat dengan mudah dikomsumsi di area hiburan.

\footnotetext{
${ }^{11}$ sLihat, Al-Ahmady Abu An-Nur,Narkoba,Cet. I (Jakarta: Darul Falah, 2000), h.27
} 
Gaya hidup modern tidak lepas dari pengaruh miras. Kegiatan, acara dan pestapesta pada umumnya tersaji miras, terlepas dari sajian tertutup ataupun terbuka, sehingga membuat anak-anak disekitarnya melihat dan mengamati para peminum miras dan mendorongnya untuk coba-coba mengkomsumsi, yang selanjutnya dijadikan sebagai minuman yang biasa-biasa saja.

Gaya hidup seperti ini hendaknya membuat orang tua selalumemproteksi anaknya dan memperhatikan sekelilingnya. Jangan sampai berdampak buruk pada anak-anak, orangtua dan orang-orang sekitarnya.

c. Pengaruh Teman

Teman- teman mempunyai pengaruh besar terhadap perilaku minum minuman keras, oleh karena mereka merasa dekat satu sama lain, senasib, sepenanggungan sehingga terciptalah solidaritas yang tinggi. Dengan demikian mereka akan mudah melakukan hal-hal yang dianggap menyenangkan kelompoknya, tanpa memikirkan baik atau buruknya perilaku tersebut, termasuk peringai minum miras. Awalnya dari pertemanan, lama kelamaan menjadi kebiasaan buruk.

d. Pengaruh globalisasi ${ }^{12}$

Perkembangan teknologi, informasi dan audiovisual yang semakin canggih, akibatnya banyak budaya asing yang masuk ke Indonesia melalui media tersebut. Budaya asing yang terbiasa dalam hura-hura dan miras lambat laun diketahui oleh anak generasi bangsa kita, karena pengaruh budaya asing ini membuat generasi muda kadang-kadang lupa akan budayanya sendiri.

Perubahan-perubahan nilai sosial sebagai konsekwensi modernisasi merupakan faktor yang turut berperan pada penyalahgunaan minuman memabukkan seperti miras.

\section{Upaya Pemerintah Daerah Mengawasi dan Mengendalikan Peredaran Miras}

Larangan penjualan minuman keras golongan A (alkohol dibawah 5 persen) di minimarket mulai berlaku kemarin (16/4). Namun, sebagai pengecualian, Kementerian Perdagangan (Kemendag) masih tetap mengizinkan penjualan minuman keras golongan A tersebut di semua kawasan wisata.

"Ada pengecualian untuk di daerah wisata, masih diperbolehkan tapi dengan syarat-syarat tertentu," ujar Dirjen Perdagangan Dalam Negeri Kemendag Srie Agustina dikantornya kemarin (16/4).

Ketentuan itu merupakan pe-tunjuk teknis dari Permendag Nomor 06/MDAG/PER/1/2015 tentang pengendalian dan pengawasan terhadap pengadaan, peredaran, dan penjualan minuman beralkohol. Srie menegaskan, pengecualian itu tidak hanya berlaku untuk Pulau Bali saja, tapi juga di semua objek wisata seluruh Indonesia. Asalkan, kawasan tersebut resmi ditetapkan sebagai objek wisata oleh

${ }^{12}$ Dwi Yanny L, Narkoba Pencegahan dan Penanganannya, (Jakarta: Elex Media Komputindo, 2001), h. 


\section{Pemerintah Daerah (Pemda). ${ }^{13}$}

Dalam Peraturan Daerah Makassar tentang pengawasan, pengendalian, pengedaran dan penjualan serta perizinan tempat penjualan minuman beralkohol, disebutkan bahwa minuman beralkohol adalah semua minuman yang mengandung ethanol yang diproses dari bahan hasil pertanian yang mengandung ethanol yang diproses dari bahan hasil pertanian yang mengandung karbohidrat dengan cara fermentasi tanpa destilasi baik dengan cara memberikan perlakuan terlebih dahulu atau tidak, maupun yang diproses dengan cara mencampur konsentrat dengan ethanol atau dengan cara pengecaran minuman mengandung ethanol.

Jadi minuman beralkohol telah dibatasi dan dikategorikan sebagai barang larangan karena minuman tersebut telah difermentasi dan atau tidak destilasi dengan cara tradisional ataupun modern dan yang sangat penting digarisbawahi bahwaminuman beralkohol merupakan produk yang sangat terkait dengan efek kesehatan dan moral masyarakat, sehingga perlu ketentuan pelaksanaan yang mengatur mengenai pengawasan dan pengendalian, peredaran, penjualan dan perizinan tempat penjualan minuman beralkohol.

Umumnya masyarakat mendukung diterapkannya Perda miras, akan tetapi praktek pelaksanaannya belum maksimal mendapat dukungan dari aparat pemerintah. Hal itu terbukti masih kurangnya petugas khusus yang mengawasi jalannya program pelaksanaan perda miras disbanding dengan luas wilayah kota Makassar.

Sesungguhnya alasan utama pembatalan Perda miras bukan dalam rangka menegakkan demokrasi lokal dan bukan pula merupakan respons terhadap hukum yang sebelumnya. Namun lebih karena dilatarbelakangi oleh banyaknya kerusuhan, tawuran, dan pesta miras bahkan tidak mengenal orang tua, dewasa bahkan anak-anak ikut terlibat sehingga timbullah keinginan untuk memberantas kenakalan remaja, tawuran, dan keributan dengan cara menerapkan Perda larangan minum minuman beralkohol.

Peluang utama bagi pemerintah daerah untuk memanfaatkan kebebasan membuat dan merancang serta menerapkan kebijakan lokal yang akan mengatur dan membuat kebijakan yang berkaitan dengan wilayah merahnya, termasuk Perda minuman beralkohol.

Secara konseptual Perda miras diprakarsai oleh Walikota setempat dan dalam perumusan dan pembuatannya pemerintah melibatkan lembaga organisasi masyarakat, misalnya Muhammadiyah, Nahdatul Ulama (NU), tokoh-tokoh agama non-muslim lainnya, tokoh-tokoh masyarakat, tokoh pemuda, dan LSM-LSM setempat serta Komite Persiapan Penegakan Syari'at Islam (KPPSI).

Perda miras yang dirumuskan pemerintah dan disahkan untuk kemudian dilaksanakan di daerahnya masing-masing sebagai wujud implementasi demokrasi

\footnotetext{
${ }^{13}$ http://www.kemenperin.go.id/artikel/11711/Kawasan-Wisata-Boleh-Jual-Miras
} 
otonomi daerah dan salah satu dari sekian perda tersebut telah dilaksanakan di tiaptiap daerah utamanya Kota Makassar dan jajarannya hingga ke kelurahan setempat dengan mengawalan ketat oleh satpol PP .Perda ini berkaitan dengan perda minuman beralkohol dengan tujuan tingkat kriminalitas berkurang sehingga membuat sebagian besar masyarakat merasa aman. perda itu hanya mengatur, mengawasi, peredaran, penjualan, dan perizinan serta perdagangan minuman beralkohol, dan sanksi yang dituangkan dalam perda itupun mengacu pada aturan hirarki perundangan dimana hukum yang dipakai adalah hukum nasional,

Makassar sebagai masyarakat yang terkontaminasi dengan budaya luar, dimana budaya, kebiasaan-kebiasaan dari luar dengan mudahnya dapat diadopsi oleh masyarakatnya. Begitu pula dengan minuman-minuman beralkohol sangat sulit untuk melarang beredar, dan masuknya di Kota Makassar, olehnya itu pemerintah setempat hanya bisa mengawasi dan mengurangi perizinan, penjualan, perdagangan minuman beralkohol dengan bekerja sama dengan tim yang telah ditunjuk oleh Walikota Makassar.

\section{E. PENUTUP}

\section{Kesimpulan}

a. Kata miras dipahami sebagai nama minuman yang membuat peminumnya mabuk atau kehilangan kesadaran.

b. Faktor penyebab seseorang mengkonsumsi miras antara lain: Faktor Keluarga, Faktor Lingkungan Tempat Tinggal, Pengaruh Teman, Pengaruh globalisasi.

c. pemerintah setempat mengawasi dan mengurangi perizinan, penjualan, perdagangan minuman beralkohol dengan bekerja sama dengan tim yang telah ditunjuk oleh Walikota Makassar melalui PERDA tentang minuman beralkohol.

\section{Implikasi}

a. Umumnya masyarakat mengharapkan penerapan Perda miras dapat mengurangi tingkat kriminalitas di kota Makassar.

b. Perlu merangkul semua stokhoulder untuk menyamakan persepsi dalam hal pengawasan, peredaran miras di Makassar. 


\section{Daftar Pustaka}

Departemen Agama RI, Al-Quran danTerjemahnya,:YP. Penterjemah Al-Quran PT. Bumi Restu, 1976-1977.

Efendi, Bahtiar. Islam dan Negara: Transformasi Pemikiran dan praktik Politik Islam di Indonesia .Jakarta: Paramadina, 1998.

Faisal, A. "Rekontruksi Syariat Islam: Studi tentang pandangan ulama terhadap syariat Islam di Sulawesi Selatan" (Disertasi), Yogyakarta: Program Pascasarjana UIN SunanKalijaga, 2004.

Al-Ghzali Al-Imam, al-Islamiy, Ihya 'Ulum al-Din, juz I, Beirut Libanon: Dar Al-Kitab al-Islamy, t. th., " '

Geertz, Clifford. Santri, Abangan, danPriyayi. Jakarta, Pustaka Jaya, 1989.

Haidar M. Ali, Nahdatul Ulama dan Islam di Indonesia: Pendekatan Fiqh dalam Politik, (Gramedia Pustaka Utama : Jakarta, 1994

Mattulada.SatuLukisanAnalitisTerhadapPolitikAntropologi Orang Bugis. Yogyakarta, GadjahMada University Press 1985.

A'la Al-Maududi Abdul, Islamic Law and Constitution.Jama'ah al-Islamiyah Publication: Karachi, 1995

Muhammad 'Abbas Husni, Al-Figh Al-Isdlmy, AfaqihwaTathawwuruh, Mekah: Rabithah al-Alamiy al-Islamiy, 1402.

Miles. Matthew B \& A. Michel Huberman.Analisis Data Kualitatif.Jakarta, UI Press. 1992,

Nasution Harun, Teologi Islam Rusional ; Apresiasi Terhadap Wacana dan praktis Harun Nasufion, (Cet I, Ciputat Press : Jakarta, 2001

Qodir, Zuly. Syariah Demokratik Pemberlakuan Syariat Islam di Indonesia. Yogyakarta: Pustaka Pelajar, 2004.

RaharjoSatjipto, SosiologiHukum, Perkembangan, Metode Dan PilihanMasalah, Muhammadiyah University Pres : Surakarta, 2002.

RahmanFazlul, Islam dan Modernitas: Tentang Transformasi Intelektuals (Islam and Modernity Transformation of an Intelectual Tradition), cet II, Mizan : Bandung, 1995

Said al-Asmawy, Muhammad. Kritik Nalar Syariah. Yogyakarta, LKJS, 2004.

Surdjo, dkk., 1993, Agama dan Perubahan Sosial; Studi Tentang Hubungan Antara Islam, Masyarakat dan Struktur Sosial-Politik di Indonesia, (Yogyakarta, PAU UGM).

Syafie Inul Kencana, SistemPemerintahan Indonesia, Rineka Cipta : Jakarta, 2002

Syaltut Mahmud, Al-Isldm 'AqtdahwaSyari'ah, t. tp.: Dar al-Qalam, t. th.

TaimiyahIbnu, Al-Siyasah al-Syarifah, (Cairo, 1951

Tomasic Roman, "The Sociology of Legislation" dalam 'Legislation and Society in Australia, dihimpunoleh Roman Tomasic, Sydney: The Law Foundation of New South Wales, 2000.

Undang-undang Otonomi Daerah

Yatim, Badri. Sejarah Peradaban Islam.Jakarta.PT RadjaGrafindo, 2000.

http://glorianet.org/berita/b6323.html, "Warga Non-Muslim Mendukung Perda Syariah di 
Bulukumba" di akses tanggal 17 Mei 2006.

http://www.gatra.com/2006-05-01/majalah/diaksestanggal 21 Mei 2005.

http://Wzbut-tahrir.or.idYmam.php?page=alislarn\&id=311 diaksestanggal 21 Mei 2006. http://www.zenit.org/engiish/repriting.html.

http://www.csrc.or.id/research/index.php7detail

http://www. go.to/ambon

http://anrusmath. Wordpress.com/2008/12/23/rele 